\section{Seasonal Incidence}

A higher frequency of megaloblastic anaemia in pregnancy towards the end of winter and early spring was noted by Gatenby (1956), Thompson (1957), Forshaw (1957), and Coyle and Geoghegan (1962). Others have not observed this distribution in their cases (Giles and Shuttleworth, 1958 ; MacKenzie and Abbott, 1960 ; Lowestein et al., 1966b). In this study the frequency was three times as high in January to March as in the latter half of the year. As pointed out by others this is probably due to a decline in the availability of dietary folate and lack of fresh vegetables.

\section{Diagnosis of Megaloblastic Haemopoiesis}

It is clear that there are no reliable "diagnostic aids" in the diagnosis of megaloblastic anaemia in pregnancy other than the demonstration of megaloblastic haemopoiesis by marrow aspiration. Red cell folate is abnormally low in only half the patients, and serum folate levels are low in pregnancy irrespective of the state of haemopoiesis. The failure of red cell folate to reflect folate deficiency is due to the relatively slow turnover of red cells. Folate is incorporated at the time of red cell formation, and there is possibly some turnover of folate in reticulocytes, since these have a relatively high folate content, but thereafter folate appears to be locked in the red cell until the end of its life-span. Thus in disorders of recent onset the red cell folate level underestimates the frequency and degree of folate deficiency, and for this reason does not always mirror folate status.

\section{Summary}

The addition of $100 \mu \mathrm{g}$. of folate to a normal diet resulted in elevation of the red cell folate level, which was maintained at the higher level after the 30th week of pregnancy. It is suggested that $100 \mu \mathrm{g}$. of pteroylglutamic acid daily is satisfactory as a folate supplement in pregnancy.

Megaloblastic haemopoiesis was found in $13 \%$ of 105 women given only iron in pregnancy and in $5 \%$ of women given iron and $100 \mu \mathrm{g}$. of folate daily. None were anaemic and only three showed minor changes in peripheral blood films.
Megaloblastic change was three times as frequent during the late winter months as compared with the latter half of the year. The women whose marrows showed megaloblastic features in late pregnancy were found to have significantly lower red cell folate values at the 15 th week of pregnancy as compared with the patients who remained normoblastic, suggesting nutritional folate deficiency as the underlying causative factor.

Women who aborted had the same red cell folate values in early pregnancy as other women in the survey. There was no relation between birth weight and red cell folate levels.

We are indebted to Professor $P$. Huntingford for allowing us to make these observations on patients under his care, to the nursing staff of the antenatal clinics for their help, and to Miss Edith Tripp for considerable technical help. We are indebted to Glaxo Laboratories for providing the tablets and for financial assistance.

REFERENCES

Beaven, G. H., Dixon, G., and White, J. C. (1966). Brit. F. Haemat., 12, 777.

Brit. med. 7., 1964, 2, 1248.

Chanarin, I., Rothman, D., Ardeman, S., and Berry, V. (1965a). Brit. J. Haemat., 11, 557

Chanarin, I., Rothman, D., and Berry, V. (1965b). Brit. med. F., 1, 480

Chanarin, I., Rothman, D., Perry, J., and Stratfull, D. (1968). Brit. med. 7., 2, 394.

Coyle, C., and Geoghegan, F. (1962). Proc. roy. Soc. Med., 55, 764.

Dacie, J. V., and Lewis, S. M. (1963). Practical Haematology, 3rd ed. London.

Dawson, D. W., More, J. R. S., and Aird, D. C. (1962). Lancet, 2, 1015 deLeeuw, N. K. M., Lowenstein, L., and Hsieh, Y.-S. (1966). Medicine (Baltimore), 45, 291.

Forshaw, J. W. B. (1957). Lancet, 1, 1249.

Gatenby, P. B. B. (1956). Proc. Nutr. Soc., 15, 115

Gatenby, P. B. B. (1956). Proc. Nutr. Soc.,

Gatenby, P. B. B. (1960). Lancet, 2, 1004.

Giles, C., and Shuttleworth, E. M. (1958). Lancet, 2, 1341.

Hansen, H. A. (1964). On the Diagnosis of Folic Acid Deficiency. Stockholm

Hansen, H., and Rybo, G. (1967). Acta obstet. gynec. scand., 46, Suppl. No. $7,107$.

Lowenstein, L., Brunton, L., and Hsieh, Y.-S. (1966b). Canad. med. Ass. 7., 94, 636.

Lowenstein, L., Cantlie, G., Ramos, O., and Brunton, L. (1966a) Canad. med. Ass. Ұ., 95, 797.

MacKenzie, A., and Abbott, J. (1960). Brit. med. f., 2, 1114

Temperley, I. J., Meehan, M. J. M., and Gatenby, P. B. B. (1968). Brit. f. Haemat., 14, 13.

Thompson, R. B. (1957). Lancet, 1, 1171

Toepfer, E. W., Zook, E. G., Orr, M. L., and Richardson, L. R. (1951). Folic Acid Content of Foods. Agriculture Handbook, No. 29. Washington.

Turchetti, L. C., Combrink, B., Krawitz, S., and Metz, J. (1966). Amer. 7. clin. Nutr., 18, 249 .

Varadi, S., Abbott, D., and Elwis, A. (1966). \%. clin. Path., 19, 33. Willoughby, M. L. N.' (1967). Brit. F. Haemat., 13, 503.

\title{
Normal Dietary Folate, Iron, and Protein Intake, with Particular Reference to Pregnancy
}

\author{
I. CHANARIN,* M.D., B.SC., D.C.P., M.C.PATH.; DOREEN ROTHMAN, $\dagger$ B.SC., M.R.C.O.G. \\ JANET PERRY, $\ddagger$ B.SC. ; D. STRATFULL,§ F.I.M.L.T.
}

Brit. med. F., 1968, 2, 394-397

Estimates for the folate content of a normal daily diet range from $53 \mu \mathrm{g}$. (Read et al., 1965), 52 to $97 \mu \mathrm{g}$. (Pace et al., 1960), $62 \mu \mathrm{g}$. (Denko et al., 1946), $47 \mu \mathrm{g}$. for a poor diet, $157 \mu \mathrm{g}$. for a low-cost diet, and $193 \mu \mathrm{g}$. for a high-cost diet (Mangay Chung et al., 1961), $101 \mu \mathrm{g}$. for elderly patients in hospitals, $145 \mu \mathrm{g}$. for the elderly at home, and $223 \mu \mathrm{g}$. for young controls (Hurdle, 1967), $157 \mu \mathrm{g}$. as "free" folate and $689 \mu \mathrm{g}$. as total folate (Butterworth et al., 1963), $400 \mu \mathrm{g}$. (Jukes, 1961), $380 \mu \mathrm{g}$. for a rural and $650 \mu \mathrm{g}$. for an urban diet (Santini

- Reader in Haematology, St. Mary's Hospital Medical School, London W.2.

t Lecturer in Obstetrics, St. Mary's Hospital Medical School, London W.2.

7 Technical Officer, M.R.C. Experimental Haematology Research Unit, London $\mathbb{W} .2$.

$\$$ Chief Technician, Department of Obstetrics, St. Mary's Hospital, London $\mathbf{W} .2$. et al., 1962) to 1,000 to $1,500 \mu \mathrm{g}$. (Jandl and Lear, 1956). Some of these data have been compiled from food tables (generally unreliable as regards folate values); others by direct microbiological assay of food extracts with either Streptococcus faecalis or Lactobacillus casei; and, finally, some data have been derived by microbiological assay after treatment of the food with enzymes that release complex forms of folate not directly available for assay. Further, food folate is labile, being lost on storage, and over $90 \%$ of the folate may be lost during. cooking. Failure to use appropriate preservatives in preparing food samples may also have led to marked loss of folate before assay. The marked variation in the published data for food folate reflects these uncertainties in technique.

As part of a study on the folate requirements in pregnancy the dietary folate intake was determined by assay of food as 
cooked and consumed by women attending the antenatal clinic at St. Mary's Hospital. Iron and protein content were also measured. Assay of vitamin $\mathrm{B}_{12}$ could not be done, as the ascorbate preservative destroyed some half to two-thirds of added vitamin $B_{12}$.

There is a greater consensus about the dietary content of iron and protein than of folate. The National Food Survey Committee (1966) found a daily iron intake of $14.1 \mathrm{mg}$. in 1964, and a recent survey by Davis et al. (1967) also noted a mean iron intake of $14.1 \mathrm{mg}$. each day by women.

\section{Methods}

Collection of food.-Food for assay was collected in a weighed 5-litre polyethylene container with $500 \mathrm{ml}$. of $0.1 \mathrm{M}$ phosphate buffer and $3 \%$ ascorbate at a final $p H$ of 7 . At the end of each 24-hour food collection the container was returned to the laboratory, weighed, its contents homogenized, and $100-\mathrm{ml}$. aliquots stored at $-20^{\circ} \mathrm{C}$.

Treatment of Food Homogenate before Folate Assay.-Triplicate quantities of food were processed. Four grammes of the food homogenate were made to $50 \mathrm{ml}$. in $0.1 \mathrm{M}$ phosphate buffer containing $0.1 \%$ ascorbate at $\mathrm{pH} \mathrm{7,} \mathrm{and} \mathrm{heated} \mathrm{at} 121^{\circ} \mathrm{C}$. for 15 minutes. Half $(25 \mathrm{ml}$.) was removed for assay of "free" folate. This was made up to $200 \mathrm{ml}$. with distilled water, filtered, and the clear filtrate retained for assay. The second portion ( $2 \mathrm{~g}$. in $25 \mathrm{ml}$.) was mixed with $25 \mathrm{mg}$. of powdered chick pancreas (Difco), suspended in $2 \mathrm{ml}$. of phosphateascorbate buffer, and $1 \mathrm{ml}$. of freshly prepared $2.5 \%$ ascorbic acid added. After incubation for 18 hours at $37^{\circ} \mathrm{C}$. a further $1 \mathrm{ml}$. of $2.5 \%$ ascorbate was added and the mixture autoclaved at $121^{\circ} \mathrm{C}$. for five minutes. The mixture was finally made up to $200 \mathrm{ml}$. with water, filtered, and the clear filtrate retained for assay. The $\mathrm{pH}$ and amounts of ascorbate used had been found to give the highest yield of folate and satisfactory recovery of added folate both in the "free" and in the polyglutamate form.

Controls for Folate Assay.-Folate content of chick pancreas was subtracted by carrying out the determination with pancreatic extract in equivalent amounts of buffer instead of food homogenate, the preparation being treated in the same way as the food homogenate. Food homogenate $(4 \mathrm{~g}$.) was also assayed after the addition of $0.5 \mathrm{~g}$. of standard yeast preparation known to contain $20 \mu \mathrm{g}$. of the polyglutamate form of folate and 0.3 $\mu$ g. of "free" folate. The mean recovery of polyglutamate was $104 \%$ of the amount added and the recovery of free folate was $113 \%$ (Fig. 1).

Microbiological Assay.-All samples after preparation were assayed with Lactobacillus casei by the methods described by Toepfer et al. (1951) with $1 \mathrm{~g}$. of ascorbate added to every

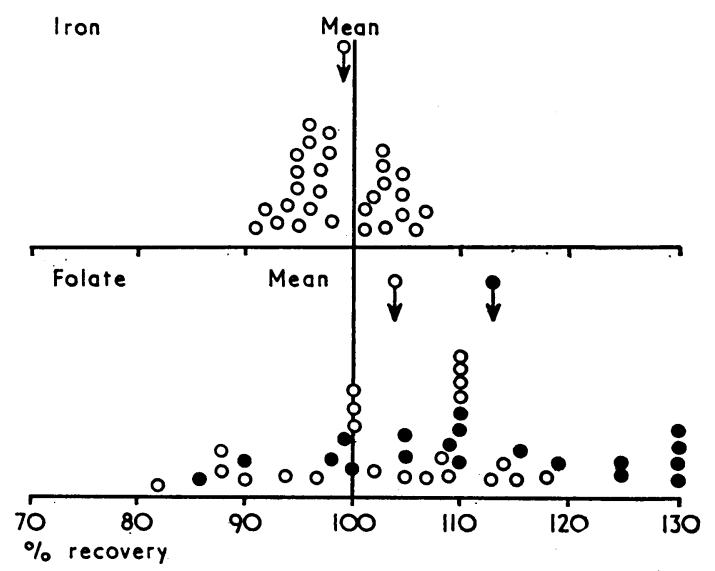

FIG. 1.-Percentage I . very of folate in the form of yeast and ferrous sulphate added to a hon. "enate of a 24 -hour food collection ( $C$ "free" f(i. ite; $O$ total folate).
$500 \mathrm{ml}$. of medium. Many were also assayed with Str. faecalis as the test organism.

Iron Estimation.-Six millilitres of food homogenate was transferred to a silica crucible previously cleaned with dilute hydrochloric acid and ashed in a muffle furnace. After cooling, $2 \mathrm{ml}$. of concentrated hydrochloric acid was added and the crucible was covered with a watch-glass and heated gently for 30 minutes; it was then cooled and the contents were filtered into a graduated flask and diluted to $100 \mathrm{ml}$. with distilled water. Ten millilitres of this solution was taken and to this $3 \mathrm{ml}$. of acetate buffer, $2 \mathrm{ml}$. of hydroquinone solution, and $2 \mathrm{ml}$. of $\alpha \mathrm{a}^{\prime}$-dipyrolyl solution were added and mixed. The optical density was measured at $520 \mathrm{~m} \mu$. A blank determination in reagents alone was used in the reference cell, and the amount of iron present was read from a standard graph. In each experiment two standard solutions were measured as controls, and duplicate samples were taken for analysis. The iron content was also assayed after the addition of $1 \mathrm{ml}$. of a solution of $50 \mu \mathrm{g}$. of $\mathrm{FeSO}_{4} / 100 \mathrm{ml}$. to the homogenate, and the recovery ranged from 91 to $107 \%$, with a mean of $99 \%$ (Fig. 1).

Protein Estimation.-A microKjeldahl method was employed. Duplicate samples of $0.2 \mathrm{ml}$. of food homogenate were transferred to digestion tubes, $2 \mathrm{ml}$. of digestion mixture was added, and the tubes were placed on a heating rack. The mixture was allowed to digest until the contents of the tube were colourless. This took one to three hours. Two blank tubes containing $2 \mathrm{ml}$. of digestion mixture only were used as controls. The contents were cooled and transferred to the Kjeldahl apparatus with $10 \mathrm{ml}$. of $40 \% \mathrm{NaOH}$. The ammonia produced was collected into a flask containing $5 \mathrm{ml}$. of boric acid and indicator solution and then titrated against $\mathrm{N} / 70$ $\mathrm{H}_{2} \mathrm{SO}_{4}$.

\section{Patients Co-operating in Study}

Pregnant women attending the antenatal clinic at St. Mary's Hospital were asked to prepare all their food in duplicate for a period of seven days. Each was given $£ 5$ to cover additional expenditure in that period. The equivalent of any uneaten food was removed from the duplicate plate before the contents were placed in the container with ascorbate-buffer. All foods, fruit, sweets, alcoholic and other drinks, etc., consumed were also added to the container, which was stored in the cold or in a cool place. Each patient wrote down the items of diet she had consumed each day. In all, 16 women carried out daily food collections.

In addition red cell and serum folate estimations were carried out at about the 15th, 30th, and 37th week of pregnancy and a marrow aspiration was performed at the end of pregnancy to determine the character of haemopoiesis and the state of iron stores. These were all healthy women who were gaining weight at the normal rate throughout pregnancy and had a normalsized foetus at term.

As these women were taking part in a trial designed to determine folate requirements in pregnancy some were having tablets containing $260 \mathrm{mg}$. of ferrous fumarate and $100 \mu \mathrm{g}$. of folate once daily and the rest were having tablets containing only iron. These tablets were not added to the food collection.

Ten 24-hour hospital diets were also assayed. Each diet was collected from one of the wards as it was being issued for consumption to patients. All these studies were carried out between February and September 1967.

\section{Results}

Subjects Studied.-Race, age, parity, and husband's occupation are shown in Table I. All the patients maintained adequate haemoglobin levels throughout pregnancy. All had received 
TABLE I.-Subjects Studied

\begin{tabular}{|c|c|c|c|c|c|c|c|c|}
\hline \multirow{2}{*}{ Subject } & \multirow{2}{*}{ Race } & \multirow{2}{*}{ Age } & \multirow{2}{*}{ Parity } & \multirow{2}{*}{ Husband's Occupation } & \multirow{2}{*}{$\begin{array}{c}\text { Hb at } \\
38 \mathrm{w} . \\
\text { (g./100 ml.) }\end{array}$} & \multicolumn{3}{|c|}{ Red Cell Folate (m $\mu \mathrm{g} . / \mathrm{ml}$ ) } \\
\hline & & & & & & $\pm 15 \mathrm{w}$ & $30 \mathrm{w}$. & $38 \mathrm{w}$. \\
\hline $\begin{array}{c}1^{*} \\
2^{*} \\
3 \\
4 \\
5 \\
6^{*} \\
7 \\
8^{*} \\
9^{*} \\
10\end{array}$ & $\begin{array}{l}\text { Irish m. to Indian } \\
\text { English } \\
\text { English } \\
\text { Scottish } \\
\text { English } \\
\text { English } \\
\text { English } \\
\text { English } \\
\text { English } \\
\text { South American m. to }\end{array}$ & $\begin{array}{l}24 \\
23 \\
23 \\
22 \\
37 \\
29 \\
29 \\
26 \\
20 \\
28\end{array}$ & $\begin{array}{l}0+1 \\
0 \\
0 \\
0 \\
1 \\
0 \\
0+1 \\
0 \\
0 \\
0\end{array}$ & $\begin{array}{l}\text { Industrial designer } \\
\text { Motor mechanic } \\
\text { Motor mechanic } \\
\text { Engineer } \\
\text { Brewer } \\
\text { Architect } \\
\text { Salesman } \\
\text { Draughtsman } \\
\text { Shipbroker } \\
\text { Land developer }\end{array}$ & $\begin{array}{l}14 \cdot 3 \\
12 \cdot 2 \\
12 \cdot 0 \\
12 \cdot 2 \\
11 \cdot 8 \\
12 \cdot 4 \\
12 \cdot 2 \\
12 \cdot 8 \\
14 \cdot 6 \\
12 \cdot 2\end{array}$ & $\begin{array}{l}174 \\
120 \\
202 \\
168 \\
137 \\
282 \\
150 \\
144 \\
121 \\
106\end{array}$ & $\begin{array}{r}157 \\
132 \\
62 \\
97 \\
84 \\
328 \\
80 \\
105 \\
112 \\
226\end{array}$ & $\begin{array}{r}209 \\
180 \\
51 \\
96 \\
133 \\
250 \\
77 \\
144 \\
139 \\
220\end{array}$ \\
\hline $\begin{array}{l}11 \\
12 \\
13 \\
14 \\
15 \\
16\end{array}$ & $\begin{array}{l}\text { English } \\
\text { Irish m. to Pakistani } \\
\text { East African } \\
\text { Burmese m. to English } \\
\text { English } \\
\text { English }\end{array}$ & $\begin{array}{l}21 \\
34 \\
22 \\
25 \\
22 \\
27\end{array}$ & $\begin{array}{l}0 \\
0 \\
0+2 \\
1+1 \\
1 \\
0\end{array}$ & $\begin{array}{l}\text { Accountant } \\
\text { Photographer } \\
\text { Research chemist } \\
\text { Sales manager } \\
\text { Lorry driver } \\
\text { Press photographer }\end{array}$ & $\begin{array}{l}14 \cdot 2 \\
13 \cdot 6 \\
13 \cdot 4 \\
11 \cdot 2 \\
11 \cdot 8 \\
11 \cdot 1\end{array}$ & $\begin{array}{l}140 \\
123 \\
234 \\
146 \\
252 \\
220\end{array}$ & $\begin{array}{r}65 \\
174 \\
189 \\
178 \\
150 \\
410\end{array}$ & $\begin{array}{r}136 \\
50 \\
129 \\
96 \\
126 \\
375\end{array}$ \\
\hline
\end{tabular}

- Rectived 100- $\mu \mathrm{g}$. supplemental folate throughout pregnancy.

Table II.-Daily Dietary Iron (mg.) and Protein (g.) Intake in Pregnancy

\begin{tabular}{|c|c|c|c|c|c|c|c|c|c|c|c|c|c|c|c|c|}
\hline \multirow{2}{*}{ Subject } & \multicolumn{2}{|c|}{ Mean } & \multicolumn{2}{|c|}{ Wednesday } & \multicolumn{2}{|c|}{ Thursday } & \multicolumn{2}{|c|}{ Friday } & \multicolumn{2}{|c|}{ Saturday } & \multicolumn{2}{|c|}{ Sunday } & \multicolumn{2}{|c|}{ Monday } & \multicolumn{2}{|c|}{ Tuesday } \\
\hline & $\mathrm{Fe}$ & $\mathrm{Pr}$ & $\mathrm{Fe}$ & Pr & $\mathrm{Fe}$ & $\operatorname{Pr}$ & $\mathrm{Fe}$ & $\mathbf{P r}$ & $\mathrm{Fe}$ & $\mathrm{Pr}$ & $\mathrm{Fe}$ & $\mathbf{P r}$ & $\mathrm{Fe}$ & $\mathbf{P r}$ & $\mathrm{Fe}$ & Pr \\
\hline $\begin{array}{l}1 \\
2 \\
3 \\
4\end{array}$ & $\begin{array}{l}11.5 \\
13.7 \\
17.8 \\
10.9\end{array}$ & $\begin{array}{l}81 \cdot 6 \\
69.8 \\
69.5 \\
71 \cdot 6\end{array}$ & $\begin{array}{l}13.6 \\
14 \cdot 3 \\
15.2\end{array}$ & $\begin{array}{l}74.2 \\
59.9 \\
66.0\end{array}$ & $\begin{array}{r}7 \cdot 0 \\
14 \cdot 0 \\
15.8 \\
9.1\end{array}$ & $\begin{array}{l}98.6 \\
72.4 \\
65.6 \\
68.1\end{array}$ & $\begin{array}{r}6.5 \\
16.1 \\
15.6 \\
9.7\end{array}$ & $\begin{array}{l}91.8 \\
90.0 \\
73.3 \\
73.7\end{array}$ & $\begin{array}{r}24 \cdot 3 \\
6.4 \\
24.2 \\
8.8\end{array}$ & $\begin{array}{r}109 \cdot 3 \\
76.7 \\
73.5 \\
82.2\end{array}$ & $\begin{array}{l}4.8 \\
8.3 \\
9 \cdot 6 \\
9.8\end{array}$ & $\begin{array}{l}49.5 \\
55.5 \\
49.8 \\
78.9\end{array}$ & $\begin{array}{r}13.2 \\
17.2 \\
22.5 \\
8.9\end{array}$ & $\begin{array}{l}84.8 \\
82.3 \\
87.4 \\
70.1\end{array}$ & $\begin{array}{l}10.7 \\
10.1 \\
23.0 \\
14.9\end{array}$ & $\begin{array}{l}63 \cdot 4 \\
42 \cdot 3 \\
77 \cdot 2 \\
62 \cdot 2\end{array}$ \\
\hline $\begin{array}{l}6 \\
7 \\
8 \\
8\end{array}$ & $\begin{array}{r}13.7 \\
8.9 \\
13.4\end{array}$ & $\begin{array}{l}64 \cdot 1 \\
91 \cdot 2 \\
65 \cdot 5\end{array}$ & $\begin{array}{c}16 \cdot 3 \\
9 \cdot 4 \\
13 \cdot 3\end{array}$ & $\begin{array}{l}69.0 \\
89.5 \\
64.2\end{array}$ & $\begin{array}{l}5 \cdot 1 \\
9 \cdot 3 \\
8 \cdot 3\end{array}$ & $\begin{array}{r}56.4 \\
111.3 \\
63.5\end{array}$ & $\begin{array}{r}20.2 \\
7.3 \\
7.6\end{array}$ & $\begin{array}{l}52.8 \\
77.4 \\
84.7\end{array}$ & $\begin{array}{r}19.5 \\
8.9 \\
21.5\end{array}$ & $\begin{array}{l}51.5 \\
99.4 \\
47.9\end{array}$ & $\begin{array}{l}14 \cdot 1 \\
10 \cdot 0 \\
10.5\end{array}$ & $\begin{array}{l}78.7 \\
82.0 \\
78.3\end{array}$ & $\begin{array}{r}7.3 \\
12 \cdot 0 \\
11 \cdot 1\end{array}$ & $\begin{array}{l}65.3 \\
96.8 \\
67.5\end{array}$ & $\begin{array}{r}13.3 \\
5.7 \\
21.6\end{array}$ & $\begin{array}{l}74.8 \\
87.4 \\
52.6\end{array}$ \\
\hline $\begin{array}{l}10 \\
11 \\
12 \\
13 \\
14 \\
15 \\
16\end{array}$ & $\begin{array}{r}9.9 \\
31.4 \\
17.7 \\
12.6 \\
9.0 \\
18.5 \\
11.0\end{array}$ & $\begin{array}{l}55.1 \\
67.8 \\
67.5 \\
58.7 \\
60.5 \\
67.0 \\
70.4\end{array}$ & $\begin{array}{r}14 \cdot 8 \\
32 \cdot 6 \\
21 \cdot 9 \\
13 \cdot 6 \\
5.9 \\
24 \cdot 0 \\
8 \cdot 0\end{array}$ & $\begin{array}{l}73.5 \\
62.5 \\
71.1 \\
57.2 \\
37.6 \\
55.5 \\
50.8\end{array}$ & $\begin{array}{r}11 \cdot 0 \\
12 \cdot 8 \\
4.0 \\
12.3 \\
8.1 \\
25.8 \\
7.5\end{array}$ & $\begin{array}{l}65.7 \\
69.8 \\
66.8 \\
68.3 \\
59.7 \\
90.4 \\
66.4\end{array}$ & $\begin{array}{r}6.4 \\
31.5 \\
3.7 \\
14.5 \\
6.9 \\
17.2 \\
10.1\end{array}$ & $\begin{array}{l}36.1 \\
83.8 \\
63.6 \\
58.2 \\
51.2 \\
70.0 \\
61.9\end{array}$ & $\begin{array}{l}14.0 \\
38.1 \\
49 \cdot 6 \\
14.5 \\
8.1 \\
34.1 \\
17.9\end{array}$ & $\begin{array}{l}68.0 \\
89.0 \\
57.3 \\
63.1 \\
39.7 \\
106 \\
90.1\end{array}$ & $\begin{array}{r}7.7 \\
37.4 \\
6.9 \\
10.7 \\
13.9 \\
14.9 \\
12.2\end{array}$ & $\begin{array}{l}42.6 \\
81.6 \\
62.4 \\
50.6 \\
92.9 \\
44.1 \\
73.0 \\
\end{array}$ & $\begin{array}{r}7.7 \\
26.2 \\
25.6 \\
12.0 \\
9.8 \\
7.3 \\
11.4\end{array}$ & $\begin{array}{l}63.8 \\
88.0 \\
882.5 \\
49 \cdot 1 \\
68.1 \\
45 \cdot 0 \\
73.2\end{array}$ & $\begin{array}{r}7.7 \\
41.3 \\
12.4 \\
10.7 \\
10.3 \\
6.4 \\
9.7\end{array}$ & $\begin{array}{l}35.8 \\
66.7 \\
68.8 \\
64.6 \\
74.2 \\
58.0 \\
77.4\end{array}$ \\
\hline Mean & $14 \cdot 2$ & $69 \cdot 1$ & & & & & & & & & & & & & & \\
\hline
\end{tabular}

$1 \mathrm{~g}$. of intravenous iron before the 20th week of pregnancy, all had been given oral iron throughout pregnancy, all had normal serum iron levels throughout pregnancy, and all had demonstrable iron in the marrow at the 38th week. Seven out of the 16 patients had received $100 \mu \mathrm{g}$. of folate daily as an oral supplement throughout pregnancy. These women had higher red cell folate levels than the other ten women who had only an iron supplement (Table I). All had normoblastic haemopoiesis at the end of pregnancy.

Iron Intake.-The iron content of 97 separate 24-hour food collections was measured (Table II). The mean iron content was $14.2 \mathrm{mg}$. The mean intake per patient (column 2, Table II) varied from 8.9 to $31.4 \mathrm{mg}$./day and the daily variation was even greater-from 3.7 to $49.6 \mathrm{mg}$.

Protein Intake.-The mean protein intake by a Kjeldahl method on 97 24-hour food collections (Table II) was $69 \mathrm{~g}$., with a range from 55 to $91 \mathrm{~g}$. Daily variations were wider, from 36 to $111 \mathrm{~g}$.

TABLE III.-Dietary Folate Content Assayed with L. casei ( $\mu g / 24$ Hours)

\begin{tabular}{|c|c|c|c|c|}
\hline \multirow{2}{*}{ Subject } & \multicolumn{2}{|c|}{ "Free "* } & \multicolumn{2}{|c|}{ "Total "* } \\
\hline & Mean & Range & Mean & Range \\
\hline $\begin{array}{c}1 \\
2 \dagger \\
3 \\
4 \\
5 \\
6 \\
7 \\
8 \\
9 \\
10 \\
11 \\
12 \\
13 \\
14 \\
15 \\
16\end{array}$ & $\begin{array}{l}202 \\
101 \\
133 \\
141 \\
53 \\
271 \\
162 \\
172 \\
96 \\
199 \\
161 \\
115 \\
265 \\
97 \\
98 \\
296\end{array}$ & $\begin{array}{r}115-290 \\
24-270 \\
70-180 \\
52-197 \\
38-78 \\
60-350 \\
114-226 \\
44-430 \\
27-422 \\
150-245 \\
21-400 \\
58-285 \\
105-340 \\
47-132 \\
27-202 \\
190-400\end{array}$ & $\begin{array}{r}830 \\
945 \\
357 \\
607 \\
198 \\
1,051 \\
361 \\
265 \\
387 \\
820 \\
849 \\
355 \\
1,041 \\
529 \\
616 \\
1,615\end{array}$ & $\begin{array}{l}499-1,650 \\
570-1,430 \\
210-430 \\
310-1,150 \\
109-282 \\
650-2,070 \\
260-455 \\
180-465 \\
1,17-1,000 \\
520-1,150 \\
240-1,950 \\
240-625 \\
315-1,420 \\
90-1,237 \\
290-1,140 \\
1,090-2,300\end{array}$ \\
\hline Mean & 160 & & 676 & \\
\hline
\end{tabular}

" "Free" and "Total" equal folate assay before and after incubation with chick pancreatic extract.
Folate Intake.-The mean folate content of 111 24-hour diets in the absence of pancreatic enzyme was $160 \mu \mathrm{g}$. when L. casei was used as the assay organism (Table III) and 676 $\mu \mathrm{g}$. after the use of enzyme. The mean "free" folate intake in individual patients ranged from 53 to $296 \mu \mathrm{g}$. daily and day-to-day variations ranged from 21 to $430 \mu \mathrm{g}$. as free folate and from 90 to $2,300 \mu \mathrm{g}$. as total folate. Much lower values were obtained when Str. faecalis was used as the test organism (Table IV), with a mean of $61 \mu \mathrm{g}$. as free folate and a mean of $245 \mu \mathrm{g}$. as total folate.

Hospital Diet.-The mean folate, iron, and protein content of 10 separate 24-hour hospital diets (Table V) was 117 and

TABLE IV.-Dietary Folate as Assayed with Str. faecalis* ( $\mu g . / 24$ Hours)

\begin{tabular}{|c|c|c|c|c|}
\hline \multirow{2}{*}{ Subject } & \multicolumn{2}{|c|}{ "Free" } & \multicolumn{2}{|c|}{ "Total" } \\
\hline & Mean & Range & Mean & Range \\
\hline $\begin{array}{r}1 \\
2 \\
4 \\
9 \\
12 \\
13\end{array}$ & $\begin{array}{l}57 \\
52 \\
70 \\
34 \\
61 \\
75\end{array}$ & $\begin{array}{l}22-91 \\
19-80 \\
40-92 \\
11-77 \\
31-96 \\
25-123\end{array}$ & $\begin{array}{l}104 \\
492 \\
216 \\
184 \\
106 \\
322\end{array}$ & $\begin{array}{r}52-178 \\
130-800 \\
154-316 \\
122-246 \\
72-132 \\
84-446\end{array}$ \\
\hline Mean & 61 & & 245 & \\
\hline
\end{tabular}

* 35 food collections were assayed.

TABLE V.-Folate, Iron, and Protein Content of a 24-hour Hospital Diet

\begin{tabular}{|c|c|c|c|c|}
\hline \multirow{2}{*}{ Day } & \multicolumn{2}{|c|}{ Folate ( $\mu \mathrm{g})}$. & \multirow{2}{*}{ Iron (mg.) } & \multirow{2}{*}{ Protein (g.) } \\
\hline & Free & Total & & \\
\hline $\begin{array}{r}1 \\
2 \\
3 \\
4 \\
5 \\
6 \\
7 \\
8 \\
9 \\
10\end{array}$ & $\begin{array}{l}120 \\
33 \\
165 \\
102 \\
112 \\
68 \\
157 \\
152 \\
100 \\
156\end{array}$ & $\begin{array}{r}427 \\
280 \\
294 \\
174 \\
298 \\
465 \\
690 \\
465 \\
1,000 \\
780\end{array}$ & $\begin{array}{r}20.2 \\
9.7 \\
9.6 \\
13.2 \\
6.5 \\
12.7 \\
6.8 \\
5.6 \\
11.4 \\
16.9\end{array}$ & $\begin{array}{l}78 \cdot 2 \\
78.7 \\
62 \cdot 3 \\
49 \cdot 4 \\
52 \cdot 7 \\
88.2 \\
72.7 \\
59 \cdot 8 \\
89 \cdot 9 \\
77 \cdot 4\end{array}$ \\
\hline Mean & 117 & 487 & $11 \cdot 3$ & $70 \cdot 4$ \\
\hline
\end{tabular}


$487 \mu \mathrm{g}$. for free and total folate as assayed with $L$. casei, 11.3 mg. for iron content, and $70.4 \mathrm{~g}$. for protein content.

Correlation of Dietary Folate Intake and Red Cell Folate Levels. - There was a good correlaton between the red cell folate level on the one hand and both the free and total folate content of the diet (Fig. 2). For free folate $r=0.82$ and $P=0.001$ and for total folate $r=0.86$ and $P=0.001$.

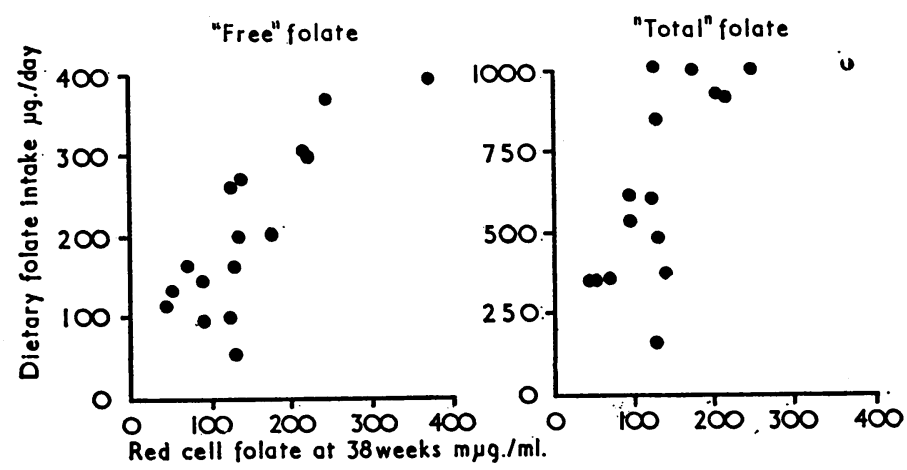

FIG. 2.-Comparison of folate intake and red cell folate level at 37 th to 38 th week in 16 healthy pregnant women.

\section{Discussion}

The mean iron intake in our group of women (14.2 mg.) is the same as that found in previous studies (Davis et al., 1967). The protein intake $(69 \mathrm{~g}$.) is less than that recommended in pregnancy and is far less than the recommendation of $110 \mathrm{~g}$. in the latter half of pregnancy (B.M.A. 1950). However, the women in this study underwent a normal pregnancy and gave birth to average-sized infants.

The folate content found is in agreement with that determined in American diets by Butterworth et al. (1963) using L. casei (Table VI). Further, there is close agreement with the American workers when Str. faecalis is used as the test organism. In the present study mean values of 61 and $245 \mu \mathrm{g}$. for free and total folate were found in 111 diets, and Butterworth et al. (1963) recorded values of 52 and $184 \mu \mathrm{g}$. for 17 American diets. Butterworth et al. (1963), like ourselves, assayed aliquots of complete 24-hour food collections. Hurdle (1967) assayed the free folate content of a large variety of cooked foods with $L$. case $i$ and therefrom calculated the free folate content of diets. The free folate intake of eight healthy young controls was $223 \mu \mathrm{g}$. (range 161 to 297) and of 16 elderly people at home $145 \mu \mathrm{g}$. (range 95 to 251). These values too are essentially in agreement with the values found by ourselves and by Butterworth's group.

TaBle VI.-Folate Content of 24-hour Diet Assayed with L. casei

\begin{tabular}{|c|c|c|c|}
\hline & & Free Folate & Total Folate \\
\hline $\begin{array}{l}\text { Present study } \\
\text { Butterworth et ai. (1963) }\end{array}$ & 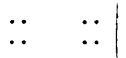 & $\begin{array}{l}160 \mu \mathrm{g} . \\
157 \mu \mathrm{g} .\end{array}$ & $\begin{array}{l}676 \mu \mathrm{g} . \\
689 \mu \mathrm{g} .\end{array}$ \\
\hline
\end{tabular}

Higher values are obtained with $L$. casei than with Str. faecalis because the former is able to utilize both methylfolates and triglutamates and there is a general consensus that values obtained with $L$. casei represent a more realistic estimate of folate content. Though substances such as thymidine may replace the folate requirement for $L$. casei this is not an important factor in the assay of biological material and foodstuffs. Thus a folate-free diet results in almost complete dis- appearance of growth-promoting material from rat liver for L. casei, indicating that other substances are not present in such material in sufficient amount to overcome the need for folate (Bennett et al., 1964).

The availability to man of the two forms of folate termed "free" and "polyglutamate" is not known. Free folate as assayed with $L$. case $i$ comprises monoglutamate and triglutamate forms as the formyl and methyl derivatives as well as some free pteroylglutamic acid. The other forms have seven (heptaglutamate) or more glutamic acid residues. These aspects are reviewed by Butterworth (1968). On the average some $85 \%$ of a small dose of tritium-labelled pteroylglutamic acid is absorbed (Anderson et al., 1960). There is no similar information available about other forms of folate. Evidence from haematological responses suggest a less adequate effect with a heptaglutamate as in yeast given orally when compared with an equimolar amount of pteroylglutamic acid (unpublished observations).

The red cell folate level is a valuable estimate of the folate status of an individual. Fig. 2 shows that there is a significant correlation between this level and the folate intake.

Hospital diets supplied substantially less folate than home diets, and, surprisingly, less iron but similar amounts of protein.

\section{Summary}

Assay of 111 24-hour food collections prepared for home consumption showed a mean folate content of $160 \mu \mathrm{g}$. as free folate and $676 \mu \mathrm{g}$. as total folate (Lactobacillus casei assay), a mean iron content of $14.2 \mathrm{mg}$. a day, and a mean protein content of $69 \mathrm{~g}$. There was a highly significant correlation between the folate intake and the red cell folate level.

Corresponding values for 10 daily collections of a hospital diet were $117 \mu \mathrm{g}$. of free and $487 \mu \mathrm{g}$. of total folate, $11.3 \mathrm{mg}$. of iron, and $70.4 \mathrm{~g}$. of protein intake a day.

We are indebted to Mrs. N. Osborn for helping in the organization of food collections and to Glaxo laboratories for generous financial help throughout the study.

\section{REPERENCES}

Anderson, B., Belcher, E. H., Chanarin, I., and Mollin, D. L. (1960) Brit. F. Haemat., 6, 439.

Bennett, M. C., Berry, V., Chanarin, I., and Ardeman, S. (1964). 7. clin. Path., 17, 27.

British Medical Association (1950). Report of the Committee on Nutrition. London.

Butterworth, C. E. (1968). Brit. F. Haemat., 14, 339.

Butterworth, C. E., Santini, R., and Frommeyer, W. B. (1963). F. clin. Invest., 42, 1929.

Davis, R. H., Jacobs, A., and Rivlin, R. (1967). Brit. med. f., 3, 711.

Denko, C. W., Grundy, W. E., Porter, J. W., Berryman, G. H. Fr.

Hurdle, A. D. F. (1967). M.D. thesis, University of London.

Jandl, J. H., and Lear, A. A. (1956). Ann. intern. Med., 45, 1027

Jukes, T. H. (1961). f. chron. Dis., 14, 283.

Mangay Chung, A. S., Pearson, W. N., Darby, W. J., Miller, O. N., and Goldsmith, G. A. (1961). Amer. भ. clin. Nutr., 9, 573.

National Food Survey Committee (1966). Domestic Food Consumption and Expenditure 1964. H.M.S.O., London.

Pace, J. K., Stier, L. B., Taylor, D. D., and Goodman, P. A. (1960). Fed Proc., 19, 415.

Read, A. E., Gough, K. R., Pardoe, J. L., and Nicholas, A. (1965). Brit. med. F., 2, 843 .

Santini, R., Berger, F. M., Berdasco, G., Sheehy, T. W., Aviles, J., and Davila, I. (1962). ₹. Amer. diet. Ass., 41, 562

Toepfer, E. W., Zook, E. G., Orr, M. L., and Richardson, L. R. (1951). Folic Acid Content of Foods, Agriculture Handbook, No. 29. Washington. 